\title{
ASSESSMENT OF POZZOLANIC MATERIAL FOR MANUFACTURING OF PORTLAND POZZOLANA CEMENT (PPC) BY THE COMPARISON OF ORDINARY PORTLAND CEMENT (OPC)
}

\author{
Adnan KHAN ${ }^{1)}$ *, Syeda RUKHSAR ${ }^{1)}$ and Muhammad ADNAN 2) \\ ${ }^{1)}$ Department of Geology, University of Karachi, Pakistan \\ ${ }^{2)}$ Epic Intercon, Pvt. Ltd., Karachi, Pakistan \\ *Corresponding author's e-mail: adkhan@uok.edu.pk
}

\begin{tabular}{|c|c|}
\hline ARTICLE INFO & ABSTRACT \\
\hline Article history: & \multirow{11}{*}{$\begin{array}{l}\text { In the present study physicochemical characterization of slate sample was carried out which was } \\
\text { collected from slate mine in Lasbela District, Baluchistan. Slate was evaluated for its effectiveness } \\
\text { as partial replacement of ordinary Portland cement }(\mathrm{OPC}) \text { in the production of Portland Pozzolana } \\
\text { cement (PPC). The grain size analysis of crushed slate sample using ball mill revealed that } \\
\text { maximum fraction retained on } 44 \mu \mathrm{m} \text { was about } 72.8 \% \text {. Sum of the major oxides }\left(\mathrm{SiO}_{2}+\mathrm{Al}_{2} \mathrm{O}_{3}+\right. \\
\left.\mathrm{Fe}_{2} \mathrm{O}_{3}\right) \text { is about } 90.09 \% \text { that meet the requirement as per ASTM C } 618(\text { minimum } 70.0 \%) \text {. Other } \\
\text { oxides including } \mathrm{SO}_{3}(<0.05), \mathrm{CaO}(4.04), \mathrm{MgO}(1.66), \mathrm{K}_{2} \mathrm{O}(0.10), \mathrm{Na}_{2} \mathrm{O}(0.16), \mathrm{TiO}_{2}(0.35) \text {, } \\
\mathrm{MnO}(<0.02) \text { and } \mathrm{Cl}(0.12) \text { also meet the international standard of ASTM C } 618 \text { for PPC. OPC } \\
\text { without and with using slate sample in a ratio of } 5 \% \text { and } 10 \% \text { with clinker was tested to measure } \\
\text { compressive strength, physical tests and setting time. The results showed that after } 5 \% \text { and } 10 \% \\
\text { replacement, insignificant effect was observed on the physical properties, setting time and } \\
\text { compressive strength in } 2-, 7-\text { and } 28 \text {-days curing. Hence, slate can be used as natural pozzolan } \\
\text { for manufacturing PPC. It is cost effective for the production of cement as well as to sustain the } \\
\text { resources of limestone for long time and reducing emission of } \mathrm{CO}_{2} \text { in the environment. It can also } \\
\text { be used in the sulfate rich environment, coastal areas especially for the construction of dams and } \\
\text { bridges. }\end{array}$} \\
\hline Received 11 August 2021 & \\
\hline Accepted 10 February 2022 & \\
\hline Available online 1 March 2022 & \\
\hline Keywords: & \\
\hline Slate & \\
\hline Pozzolan & \\
\hline PPC & \\
\hline Cement & \\
\hline Bela Distric & \\
\hline Industry & \\
\hline
\end{tabular}

\section{INTRODUCTION}

The term "pozzolan" came from a U.S. simplification of "pozzolana" which evolved from the location "Pozzuoli, Italy" where the Romans found a reactive silica-based material of volcanic origin which they called "pulvis puteolanus" (Davis, 1950; Spence and Cook, 1983). The pozzolan is a supplementary cementitious material class N. It is a siliceous material that can be used as a low-cost cement in a mortar. Pozzolana participates in a strong reaction with calcium hydroxide (i.e., lime) and other alkalis. Pozzolana is impressive at lowering the mortar's heat of hydration, which enhance its workability and durability. It is also considered to be economical and environment friendly as not involved substantial energy consumption processes. Moreover, the cost of quarrying, transportation, packaging and grinding of such materials is generally within value related to the manufacture of traditional cement (Suhendro, 2014). One of the root causes of concrete degradation are sulfate attack; this happens due to a set of chemical reactions that starts with the reaction of sulfate ions and calcium hydrate within the hardened cement paste while exposed to a sulfate environment (Mather, 1982). The resulting growth can generate significant stresses that cause cracking. The use of natural pozzolan in the concrete reduces the amount of calcium hydroxide available for the reaction, allowing the concrete to withstand the aggressive attacks by soils containing sulfates, as well as natural acidic water and seawater (Binici et al., 2007). It can also improve the concrete and mortar resistance to both sulfate attack and the alkali-silica reaction (ASR), which makes it essential to use in large concrete projects like bridges and dams (Gibbons, 1997). Only the production of cement, which is the most significant constituent of concrete, is contributing $6 \%$ of the worldwide $\mathrm{CO}_{2}$ release (WBCSD-IEA, 2009; CIF, 2003). The worldwide $\mathrm{CO}_{2}$ emission is severely affecting the earth's temperature, which causes climatic changes and global warming related issues (Humphreys and Mahasenan, 2002). Additionally, to $\mathrm{CO}_{2}$ emission, the price increment in energy for the production of cement needed in the manufacturing of cement during a desired quality are other major concerns of most cement producing countries. The development of latest and repaired existing facilities also requires huge amounts of concrete and this demand is even expected to extend with current increasing trends of urbanization. Many researchers around the globe are

Cite this article as: Khan A, Rukhsar S, Adnan M: Assessment of pozzolanic material for manufacturing of Portland Pozzolana cement (PPC) by the comparison of Ordinary Portland cement (OPC). Acta Geodyn. Geomater., 19, No. 2 (206), 119-126, 2022. DOI: 10.13168/AGG.2022.0002 


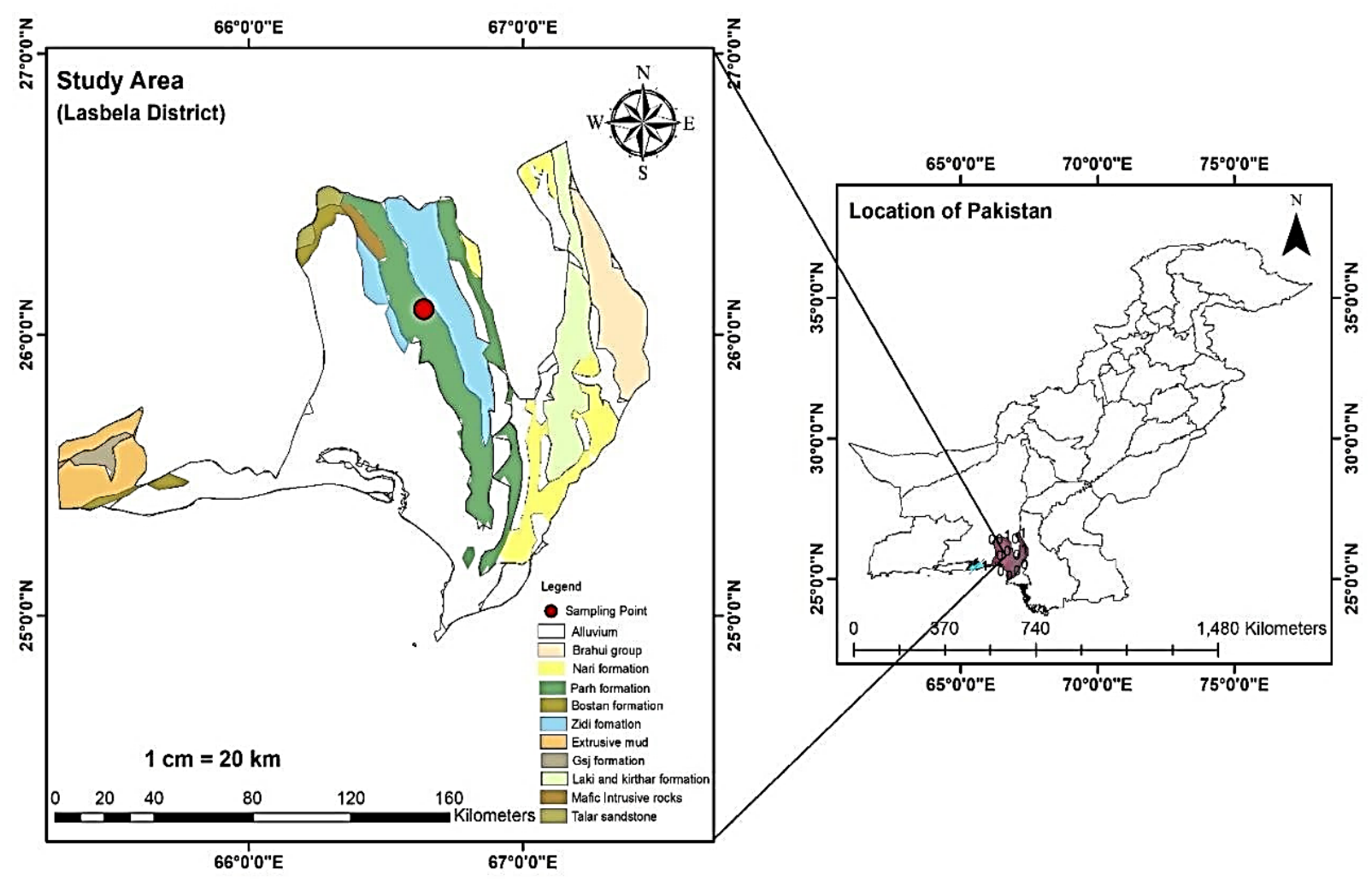

Fig. 1 Geological map of the sampling site.

currently working to reduce its environmental footprint. Trends of using innovative materials with a reduced carbon footprint, high strength, and increased design-life of concrete structures are being developed recently. There is an increasing demand of using lightweight aggregate to supply lightweight concrete for structural application and using fiber reinforcement in mortar and concrete to reduce the size of structural members (Campion et al., 2012; Ombres and Verre, 2017). Among the various technologies, the most effective way to reduce $\mathrm{CO}_{2}$ discharge is to minimize the use of clinker by replacing it partially with supplementary cementitious materials (Yang et al., 2016). Commercially available popular materials like fly ash, slag, silica fume, calcined clays, and natural pozzolan are already being used for such purposes (Hemalatha and Ramaswamy, 2017; Khurram et al., 2018). In Pakistan, many industries produce Ordinary Portland Cement (OPC) at large scale which is increasing the concentration of $\mathrm{CO}_{2}$ within the environment that create the atmospheric pollution as well as global warming. Further, resources of limestone are also decreasing. In present study, slate is examined to be served as Pozzolan that reduces the $\mathrm{CO}_{2}$ in the environment as well as sustains the resources of limestone for long time. Further, present study has focused on comparison of OPC with PPC for the investigation of durability, workability and compressive strength after addition of slate as Pozzolan material.

\section{GEOLOGY OF STUDY AREA}

Parh Formation forms thick Cretaceous succession in Kirthar-Sulaiman fold-thrust belts (Jones, 1961). It has a wide lateral extension of more than $1000 \mathrm{~km}$ with many thick outcrops exposed from Bela in the south to Mughal Kot and Dera Ghazi Khan in the north (Jones, 1961; Shah, 2009). The section within the upper reaches of the Gaj River has been designated as its type section, where it is about $268 \mathrm{~m}$ thick. The sampling site lies in Lasbela District, Baluchistan as shown in (Fig. 1). It is medium to thin-bedded hard limestone, In Mughal Kot Gorge, it is about $384 \mathrm{~m}$ thick and, in some areas, it attains a maximum thickness of about $600 \mathrm{~m}$ (Shah, 2009; Khan, 2012). Which contains subordinate marls and calcareous shale (Fatmi, 1977; Khan, 2012). The rock sample was collected from the shaly area of Parh Formation as shown in Figure 1 which has been metamorphosed locally to slate due to intense directed tectonic stress.

\section{MATERIALS AND METHODS}

In this experiment, slate sample was used as Pozzolanic material. It is sourced from an extensive deposit of slate in Baluchistan occurring at latitude of $26^{\circ} 5^{\prime} 31.00^{\prime \prime} \mathrm{N}$ and longitude of $66^{\circ} 38^{\prime} 59.80^{\prime \prime} \mathrm{E}$. The sample was collected from the slate mining site for the investigation of properties comparable with pozzolan (Fig. 2). Colors of the slate sample varied from earthy brown to dark grey. Sample was compared with standard limits of ASTM C 618.

Bulk density was found to be $0.950 \mathrm{gm} / \mathrm{cm}^{3}$ 

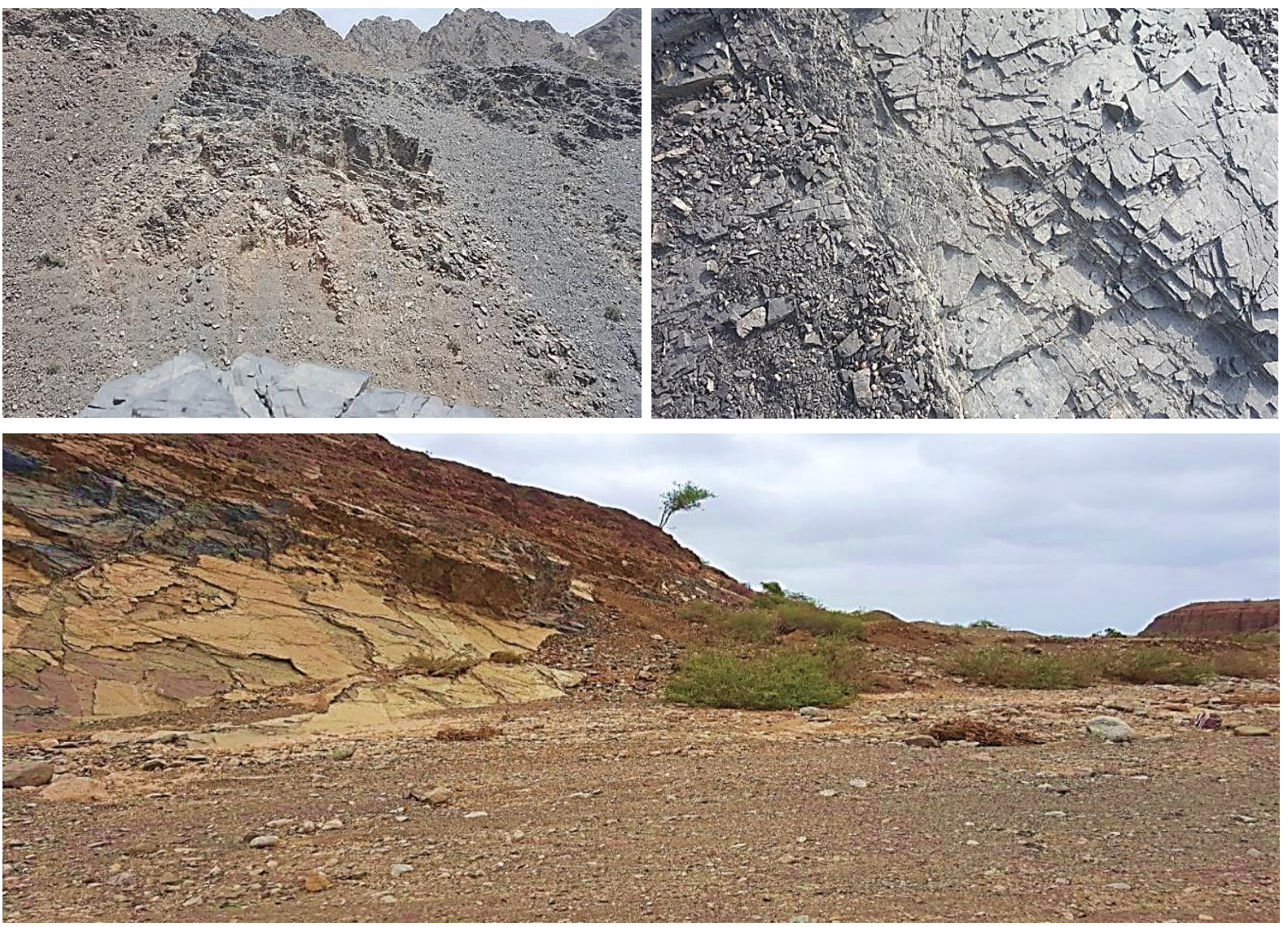

Fig. 2 Quarry site of slate locality.

Table 1 Composition of slate as natural Pozzolan.

\begin{tabular}{clr}
\hline S. No & \multicolumn{1}{c}{ Composition of Pozzolan } & (\%) \\
\hline 1 & Insoluble Residue & 84.1 \\
2 & Moisture & 0.15 \\
3 & Loss on Ignition (LOI) & 3.17 \\
4 & Reactive silica & 3.50 \\
5 & Silica $\left(\mathrm{SIO}_{2}\right)$ & 71.12 \\
6 & Alumina $\left(\mathrm{Al}_{2} \mathrm{O}_{3}\right)$ & 13.06 \\
7 & Iron oxide $\left(\mathrm{Fe}_{2} \mathrm{O}_{3}\right)$ & 5.91 \\
8 & Calcium oxide $(\mathrm{CaO})$ & 4.04 \\
9 & Calcium Carbonate $(\mathrm{CaCO})$ & 7.21 \\
10 & Magnesium oxide $(\mathrm{MgO})$ & 1.66 \\
11 & Potassium oxide $\left(\mathrm{K}_{2} \mathrm{O}\right)$ & 0.10 \\
12 & Sodium oxide $\left(\mathrm{Na}_{2} \mathrm{O}\right)$ & 0.16 \\
13 & Sulphuric anhydrite $\left(\mathrm{SO}_{3}\right)$ & $<0.05$ \\
14 & Chloride $(\mathrm{Cl})$ & 0.12 \\
15 & Alkali Eq. & 0.23 \\
16 & Density & $2.72 \mathrm{~g} / \mathrm{cm}^{3}$ \\
17 & Mohs Hardness & 2.5 \\
18 & Titanium Dioxide $\left(\mathrm{TiO}_{2}\right)$ & 0.35 \\
19 & Manganese oxide $(\mathrm{MnO})$ & $<0.02$ \\
\hline
\end{tabular}

Physicochemical analysis of slate sample was carried out in Qualitest Laboratory Services (Pvt.) Limited, Karachi. Chemical composition was determined by gravimetric titration method. Physicochemical results of pozzolan sample are summarized in Table 1. The sample was also tested for the determination of loss on ignition (LOI). Screen analysis was carried out by using sieves of mesh No. 200, 230 and 270. OPC sample contained residue of $3.1 \%$ on $45 \mu \mathrm{m}, 1.00 \mathrm{~mm}$ in expansion and consistency was about $26 \%$. The formulation of blended cement varied by substitution of ordinary 
Portland cement with pozzolana. Finely ground slate as Pozzolan was mixed with OPC in specified ratios, $5 \%$ pozzolan with clinker was about $90 \%$ and $10 \%$ pozzolana with clinker is $80 \%$. While the limestone and gypsum content were maintained constant at $5 \%$. After that the compressive strength were tested at 2, 7 and 28 days, physical test and setting time was test in a quality control department for comparison of effect after addition of slate as pozzolan in OPC.

\section{RESULTS AND DISCUSSION}

\subsection{GRAIN SIZE ANALYSIS}

Slate sample was crushed in commercial ball mill installed in Power Cement Ltd. Nooriabad. The Blain test (Grain size analysis) was carried out to identify the particle size distribution of the slate after grinding in ball mill for which results have been summarized in Table 2. Ground slate sample was passed through various screens (mesh $200(74 \mu \mathrm{m}), 230(63 \mu \mathrm{m})$, $270(53 \mu \mathrm{m}), 325(44 \mu \mathrm{m})$ and pan).

Data revealed that higher amount $(72.88 \%)$ of the crushed fraction $(<44 \mu \mathrm{m})$ was retained in the pan that fulfils the required particle size for pozzolan according to ASTM-C 618, 17a. Small size Pozzolan can fill the micro pores in the cement matrix and increase the durability of the cement significantly by changing the frame work of matrix (Sabir et al., 2001; Pan et al., 2003). Natural Pozzolan have lubricant effects on cement mortar or concrete because of their fine grain size. Moreover, it improves consistency and thus workability conditions of the concrete (Pan et al. 2003). About $<15 \%$ of sample retained on screens (mesh no. 200, 230, 325) respectively.
Table 2 Grain size analysis of ground slate sample.

\begin{tabular}{cc}
\hline Screen Analysis (US Mesh) & Weight retains (\%) \\
\hline+200 & 6.25 \\
$-200+230$ & 3.84 \\
$-230+270$ & 4.70 \\
$-270+325$ & 12.06 \\
$-325+$ pan & 72.88 \\
\hline + means Retained \\
- means Passing.
\end{tabular}

\subsection{CHEMICAL PROPERTIES OF SLATE}

Chemical results of slate sample have been summarized in Table 3. Data revealed that high silica content $(71.12 \%)$ is superseding the other oxides $\left(\mathrm{K}_{2} \mathrm{O}, \mathrm{Na}_{2} \mathrm{O}, \mathrm{TiO}_{2}, \mathrm{MnO}\right)$ which have been reported as $<1 \%$ in the sample. As per ASTM-C618, 17a; sum of the required content of $\mathrm{SiO}_{2}, \mathrm{Al}_{2} \mathrm{O}_{3}$ and $\mathrm{Fe}_{2} \mathrm{O}_{3}$ should be minimum $70 \%$ for pozzolan. Interestingly, the sum of these oxides $\left(\mathrm{SiO}_{2}, \mathrm{Al}_{2} \mathrm{O}_{3}\right.$ and $\left.\mathrm{Fe}_{2} \mathrm{O}_{3}\right)$ in slate sample are found to be $90.09 \%$ (Table 3 ). Pozzolanic reaction is mainly controlled by the active silica and alumina contents (Massazza, 2007). Hence, Lasbela slate qualified as Pozzolan material due in terms of silica content. On the other hand, concentration of $\mathrm{SO}_{3}$ and $\mathrm{MgO}$ in slate sample are found to be $<2 \%$ which is also in agreement with the specification of ASTM-C618, 17a where maximum $4 \% \mathrm{SO}_{3}$ and $5.00 \% \mathrm{MgO}$ are allowed. Contrary to that, amount of $\mathrm{CaO}$ in slate sample is found to be 4.04 which is double the prescribed value ( $<2 \%$ by mass). $\mathrm{CaO}, \mathrm{MgO}$ and $\mathrm{SO}_{3}$ are harmful materials which can damage volume stability (Canpolat et al., 2003; Çavdar and Yetgin, 2004). Values of LOI and MC contents are reported to be $0.15 \%$ and $3.17 \%$ respectively. Values of both parameters are in compliance with the corresponding standard ASTM-C618, 17a (Table 3).

Table 3 Chemical analysis of pozzolana and its comparison with ASTM C 618.

\begin{tabular}{|c|c|c|c|c|}
\hline \multicolumn{5}{|c|}{ Nature Composite Defused (Supplementary Cementitious Material Class 'N') } \\
\hline $\begin{array}{l}\text { Sr. } \\
\text { No }\end{array}$ & Chemical Composition & $\begin{array}{l}\text { Chemical } \\
\text { Formula }\end{array}$ & ASTM C 618 17-a Standard Limits & Results (mass\%) \\
\hline 1 & Silicon Dioxide & $\mathrm{SiO}_{2}$ & & 71.12 \\
\hline 2 & Aluminum Oxide & $\mathrm{Al}_{2} \mathrm{O}_{3}$ & & 13.06 \\
\hline 3 & Ferric Oxide & $\mathrm{Fe}_{2} \mathrm{O}_{3}$ & & 5.91 \\
\hline & $\mathrm{Sum}\left(\mathrm{SiO}_{2}+\mathrm{Al}_{2} \mathrm{O}_{3}+\mathrm{Fe}_{2} \mathrm{O}_{3}\right)$ & & 70.0 min. & 90.09 \\
\hline 4 & Sulphur Trioxide & $\mathrm{SO}_{3}$ & 4.00 max. & $<0.05$ \\
\hline 5 & Moisture & & 3.00 max. & 0.15 \\
\hline 6 & Loss On Ignition & & 10.00 max. & 3.17 \\
\hline 7 & Calcium Oxide & $\mathrm{CaO}$ & & 4.04 \\
\hline 8 & Magnesium Oxide & $\mathrm{MgO}$ & 5.00 max. & 1.66 \\
\hline 9 & Potassium Oxide & $\mathrm{K}_{2} \mathrm{O}$ & & 0.10 \\
\hline 10 & Sodium Oxide & $\mathrm{Na}_{2} \mathrm{O}$ & & 0.16 \\
\hline 11 & Alkali Eq & & $<1.50 \max$ & 0.23 \\
\hline 12 & Chloride & $\mathrm{Cl}$ & & 0.12 \\
\hline 13 & Titanium Dioxide & $\mathrm{TiO}_{2}$ & & 0.35 \\
\hline 14 & Manganese Oxide & $\mathrm{MnO}$ & & $<0.02$ \\
\hline
\end{tabular}




\subsection{COMPARISON OF PPC WITH OPC}

The comparative results of physicochemical parameters of OPC with PPC have been summarized in Table 4. The chemistry of cement in general and Portland cement, in particular, depends upon the chemistry of its raw Material (Lea, 1976). The OPC cement of Power Cement Limited comprises of clinker $(90.09 \%)$ followed by gypsum and limestone in the ratio of about $5.0 \%$ each. In present study, 5 and $10 \%$ Pozzolanic material was replaced with the clinker. To observe the impact on compressive strength. While the use of concrete wastes as a limestone replacement in limestone-blended cement production was study by Baylalvi and Topcu (2019). However, LOI in OPC was about $3.4 \%$ which slightly increased to $3.95 \%$ and $3.67 \%$ by the addition of $5 \%$ and $10 \%$ slate powder respectively. It is due to the fact that Pozzolanic slate is siliceous in nature which has no impact on $\mathrm{CO}_{2}$ emission. Moreover, silica was increased by the addition of $5 \%$ and $10 \%$ slate powder as Pozzolanic material was increased of silica $1 \%$ and $4 \%$ respectively. It suggests that by increasing slate as pozzolan, the silica content will rise exponentially. The concentration of oxides in OPC varied in the order of $\mathrm{CaO}(63.41 \%)>\mathrm{Fe}_{2} \mathrm{O}_{3}(4.25 \%)$ $>\mathrm{Al}_{2} \mathrm{O}_{3}(4 \%)>\mathrm{SO}_{3}(2.59 \%)>\mathrm{MgO}(2.31 \%)>\mathrm{K}_{2} \mathrm{O}$ $(0.65 \%)>\mathrm{Na}_{2} \mathrm{O}(0.21 \%)>\mathrm{Cl}(0.0243 \%)$. However, addition of 5 and $10 \%$ slate powder resulted in decrease of $\mathrm{CaO}$ content significantly as 2 and $5 \%$ respectively. While, remaining oxides slightly increased up to $<1 \%$. The comparative study of chemical and physical parameters showed that addition of slate as pozzolan in OPC makes it feasible for manufacturing of PPC. It means there is no significant effect in the character of PPC as compared to $\mathrm{OPC}$.

\subsection{LIME SATURATION FACTOR (LSF)}

Lime saturation factor of OPC sample is found to be $95.5 \%$. By the addition of $5 \%$ and $10 \%$ slate powder LSF decreased to about 87.02 and $73.66 \%$ respectively (Table 4). For the production of cement, the lime saturation factor (LSF) plays an important role, because it contains $\mathrm{CaO}$ which is the primary constituent of cement (Ingram and Daugherty, 1991). LSF decreases in PPC because of increasing silica content. Generally excessive amount of silica content creates abrasion due to its high hardness compared to ball mill hardness. Moreover, frictional abrasion creates heat energy which affects the clinker production. However, no effect of silica abrasion has been reported in the present study as the blending of silica as pozzolan material is applied after the process of clinker.

\subsection{SILICA MODULUS (SILICA RATIO)}

Silica modulus in OPC was found to be $2.47 \%$. However, by mixing the slate as 5 and $10 \%$ in OPC, silica increased slightly up to 2.55 and $2.7 \%$ respectively. It reveals that there is no significant effect of silica ratio in PPC.

\subsection{ALUMINA MODULUS (ALUMINA RATIO)}

Alumina modulus in OPC was reported to be $0.94 \%$ which slightly increased as $0.98 \%$ and $1.06 \%$ by the addition of 5 and $10 \%$ slate powder respectively. As per ASTM-C150, alumina ratio for cement production should be ranged between 1 to $4 \%$. Results of present study indicates that alumina ratio was balanced by the substitution of $10 \%$ pozzolan.

\subsection{PHYSICAL PROPERTIES}

\subsubsection{BLAIN TEST}

The blain test value of OPC was about $3505 \mathrm{~cm}^{2} / \mathrm{gm}$. However, by the addition of 5 and $10 \%$ ground slate sample, it was reported be $3554 \mathrm{~cm}^{2} / \mathrm{gm}$. This is due the fact that finer cement (due to larger surface area) is more reactive with water at early ages (Dale et al., 2008). It has been noted that, for cements of specific surface of $2000-3600 \mathrm{~cm}^{2} / \mathrm{gm}$, an increase of $1 \%$ in specific surface results in $2 \%$ and $1 \%$ increase, respectively, in 7- and 28-day strength (Troxell et al., 1968).

\subsubsection{INSOLUBLE RESIDUE (IR)}

Insoluble residue content in OPC was retained up to $3.1 \%$ on $45 \mu \mathrm{m}$. Contrary to that, the addition of 5 and $10 \%$ ground slate, the IR value varied from 2.7 to $2.9 \%$ respectively. As per ASTM-C150 for manufacturing of cement the insoluble residue should be $0.75 \%$ so the IR was high both in OPC and the slate blended cement as well.

\subsubsection{EXPANSION}

In OPC, the expansion was found to be $1.00 \mathrm{~mm}$. Contrary to that, there was no expansion reported in the slate admixture at $5 \%$ mixing. Interestingly, it remained constant by mixing up to $10 \%$ (Table 4 ).

\subsubsection{CONSISTENCY}

Consistency was about $26 \%$ in OPC and by the addition of 5 to $10 \%$ ground slate consistency slightly increased up to 0.5 to $2 \%$. The standard consistency range for OPC is $25-35 \%$. Hence, consistency of both OPC and PPC were within permissible limits.

\subsubsection{SETTING TIME}

Initial and final setting time of OPC were about 230 and 285 minutes respectively. By the addition of 5 to $10 \%$ of slate sample, the initial setting time increased from 15 to 20 minutes and final setting time increased from 5 to 10 minutes. Increase in the initial and final setting times is attributed to high content of $\mathrm{SO}_{3}$ due to the formation of sulphuric anhydride (Paraskeva et al., 2007). PPC can be used in all conditions where OPC is applicable. 
Table 4 Comparison of Ball Mill Samples with pozzolan.

\begin{tabular}{|c|c|c|c|c|c|c|c|c|c|c|c|}
\hline \multirow{3}{*}{$\begin{array}{c}\text { Contents } \\
(\%)\end{array}$} & \multicolumn{3}{|c|}{ Material Ratio (\%) } & \multicolumn{4}{|c|}{ Material Ratio (\%) } & \multicolumn{4}{|c|}{ sMaterial Ratio (\%) } \\
\hline & Clinker & Gypsum & $\begin{array}{l}\text { Lime } \\
\text { Stone }\end{array}$ & Clinker & Gypsum & $\begin{array}{l}\text { Lime } \\
\text { Stone }\end{array}$ & Pozzolana & Clinker & Gypsum & $\begin{array}{l}\text { Lime } \\
\text { Stone }\end{array}$ & Pozzolana \\
\hline & 90.0 & 5.0 & 5.0 & 85.0 & 5.0 & 5.0 & 5.0 & 80.0 & 5.0 & 5.0 & 10.0 \\
\hline L.O. I & & 3.4 & & & & 3.95 & & & & 3.67 & \\
\hline $\mathrm{SiO}_{2}$ & & 20.36 & & & & 21.71 & & & & 24.52 & \\
\hline $\mathrm{Al}_{2} \mathrm{O}_{3}$ & & 4.0 & & & & 4.22 & & & & 4.67 & \\
\hline $\mathrm{Fe}_{2} \mathrm{O}_{3}$ & & 4.25 & & & & 4.29 & & & & 4.42 & \\
\hline $\mathrm{CaO}$ & & 63.41 & & & & 61.54 & & & & 58.6 & \\
\hline $\mathrm{MgO}$ & & 2.31 & & & & 2.21 & & & & 2.22 & \\
\hline $\mathrm{K}_{2} \mathrm{O}$ & & 0.65 & & & & 0.68 & & & & 0.73 & \\
\hline $\mathrm{Na}_{2} \mathrm{O}$ & & 0.21 & & & & 0.25 & & & & 0.34 & \\
\hline $\mathrm{SO}_{3}$ & & 2.59 & & & & 2.68 & & & & 2.65 & \\
\hline $\mathrm{Cl}$ & & 0.0243 & & & & 0.0187 & & & & 0.0168 & \\
\hline LSF & & 95.5 & & & & 87.02 & & & & 73.66 & \\
\hline SM & & 2.47 & & & & 2.55 & & & & 2.7 & \\
\hline $\mathrm{AM}$ & & 0.94 & & & & 0.98 & & & & 1.06 & \\
\hline $\mathrm{C}_{3} \mathrm{~S}$ & & 63.03 & & & & 43.41 & & & & 6.98 & \\
\hline $\mathrm{C}_{2} \mathrm{~S}$ & & 10.85 & & & & 29.53 & & & & 65.03 & \\
\hline $\mathrm{C}_{3} \mathrm{~A}$ & & 3.42 & & & & 3.92 & & & & 4.9 & \\
\hline $\mathrm{C}_{4} \mathrm{AF}$ & & 12.93 & & & & 13.04 & & & & 13.45 & \\
\hline $\begin{array}{l}\text { Free } \\
\text { Lime }\end{array}$ & & 1.08 & & & & 1.2 & & & & 1.26 & \\
\hline
\end{tabular}

Physical Tests:

\begin{tabular}{l|c|c|c}
\hline Blaine $\mathrm{cm}^{2} / \mathrm{gm}$. & 3505 & 3554 & 3554 \\
Residue on $90 \mu$ & - & - & - \\
Residue on $45 \mu$ & 3.1 & 2.7 & 2.9 \\
Expansion in & 1.00 & Nil & 1.00 \\
mm. & 26 & 26.5 & 28 \\
Consistency $\%$ & & & \\
\hline
\end{tabular}

Setting Time:

\begin{tabular}{|c|c|c|c|c|c|c|c|c|c|}
\hline $\begin{array}{l}\text { Initial Setting } \\
\text { (mints.) }\end{array}$ & \multicolumn{2}{|c|}{230} & \multicolumn{4}{|c|}{245} & \multicolumn{3}{|c|}{250} \\
\hline $\begin{array}{l}\text { Final Setting } \\
\text { (mints.) }\end{array}$ & \multicolumn{2}{|c|}{285} & \multicolumn{4}{|c|}{290} & \multicolumn{3}{|c|}{295} \\
\hline $\begin{array}{l}\text { Compressive } \\
\text { strength } \\
\text { (MPa) }\end{array}$ & \multicolumn{3}{|c|}{$\begin{array}{l}\text { OPC } \\
(n=3)\end{array}$} & \multicolumn{3}{|c|}{$\begin{array}{c}5 \% \text { Pozzolan } \\
(\mathrm{n}=3)\end{array}$} & \multicolumn{3}{|c|}{$\begin{array}{c}10 \% \text { Pozzolan } \\
(\mathrm{n}=3)\end{array}$} \\
\hline 2 days & 24.20 & 23.5 & 25.3 & 21.39 & 20.20 & 20.95 & 20.79 & 20.44 & 21.35 \\
\hline 7 days & 37.35 & 36.95 & 35.2 & 34.73 & 36.5 & 35.2 & 35.21 & 35.88 & 36.2 \\
\hline 28 days & 45.53 & 44.59 & 43.95 & 43.77 & 44.87 & 43.20 & 43.27 & 43.35 & 44.5 \\
\hline
\end{tabular}

\subsubsection{COMPRESSIVE STRENGTH}

Three samples each of OPC and PPC (at 5 and $10 \%$ ) were subjected to determine the compressive strength for which the results have been summarized in Table 4. Data reveal that the compressive strength of OPC in initial 2 days varied between 23.5 to 25.3 Mps which increased up to $37.35 \mathrm{Mps}$ after 7 days and double $(45.53 \mathrm{Mps})$ the initial strength in
28 days (Fig. 3). On the other hand by substitution of 5 and $10 \%$ of clinker with slate (as PPC), compressive strength decreased during initial days (2 and 7 days) but increased after 28 days which is attributed to the occurrence of silica and the calcium hydroxide in the hardened cement paste to produce additional C-S-H (Taylor, 2008; Bustos et al., 2015). 

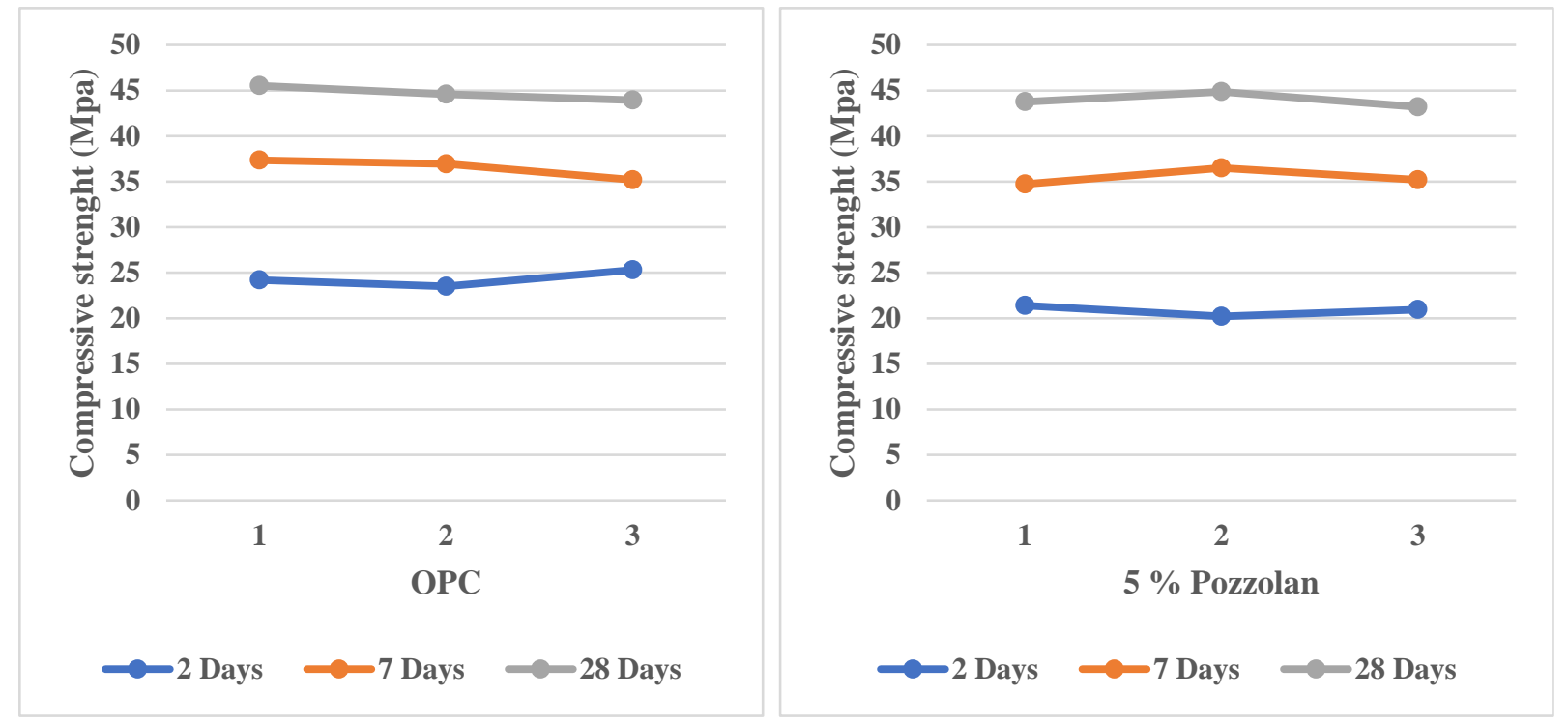

(a)

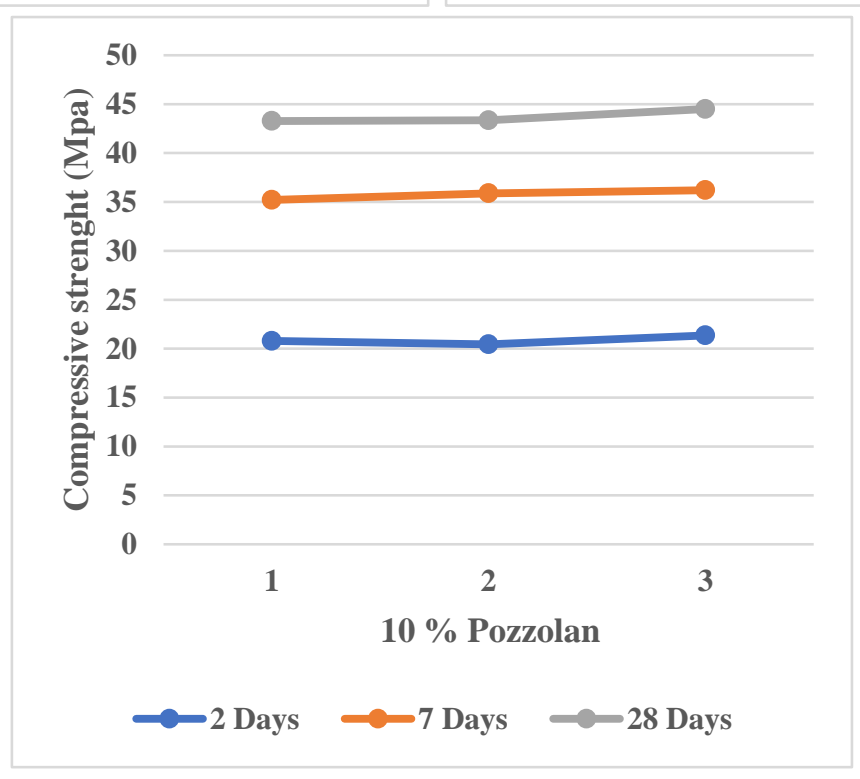

(b)

(c)

Fig. 3 Sshowing the compressive strength change of (a) OPC (b) $5 \%$ Pozzolan and (c) $10 \%$ Pozzolan with number of days.

\section{CONCLUSION}

It is concluded from the present study that slate from the Lasbela district can be used to produce pozzolan cement with the replacement of $5 \%$ and $10 \%$ of OPC with it. Addition of this slate will not affect the cement properties in terms of compressive strength, setting time and other physical properties of cement. This slate as Pozzolan can be used for massive and water associated construction projects such as dams, for which the control of the heat production is essential. Using this slate as PPC will also reduce the emission of $\mathrm{CO}_{2}$ and the environment will be free from greenhouse gas effect. A detailed study is needed to evaluate the slate resource available in the Lasbela district to fully understand its character for the sustainable utilization in cement industry.

\section{REFERENCES}

ASTM C-150: 2007, Standard Specification for Portland cement.

ASTM International: 2017, ASTM C618 - 17a Standard. Specification for Coal Fly Ash and Raw or Calcined Natural Pozzolan for Use in Concrete.

Baylavi, H. and Topcu, I.B.: 2019, The use of concrete wastes as a limestone replacement in limestoneblended cement production. Kuwait J. Sci., 46, 2, 6773.

Binici, H., Aksogan, O., Cagatay, I.H., Tokyay, M. and Emsen, E.: 2007, The effect of particle size distribution on the properties of blended cements incorporating GGBFS and natural pozzolan (NP). Powder Technol., 177, 140-147. DOI: $10.1016 /$ j.powtec.2007.03.033 
Bustos, F., Martinez, P., Videla, C. and Lopez, M.: 2015, Reducing concrete permeability by using natural pozzolans and reduced aggregate-to-pasteratio. J. Civ. Eng. Manag., 21, 2, 165-176. DOI: $10.3846 / 13923730.2013 .802719$

Campione, G., Cavaleri, L., Minafò, G. and Miraglia, N.: 2012, The use of pumice lightweight concrete for masonry applications. Mater. Struct., 45, 5, 679-693. DOI: 10.1617/s11527-011-9789-7

Canpolat, F., Yilmaz, K., Köse, M., Sümer, M. and Yurdusev, M.: 2004. Use of zeolite, coal bottom ash and fly ash as replacement materials in cement production. Cem. Concr. Res., 34, 5, 731-735. DOI: $10.1016 / \mathrm{S} 0008-8846(03) 00063-2$

Çavdar, A. and Yetgin, S. 2004. The effect of grain fineness on trasli cement properties. Turkish Civil Engineering, 17, Technical Congress (CD-ROM), Turkish Chamber of Civil Engineers, Istanbul, Turkey, 451-454.

CIF - Cement Industry Federation: 2003, Cement Industry Environment Report; Cement Industry Federation: Forrest, Australia.

Dale, B.P., Sant, G. and Weiss, J.: 2008, Early-age properties of cement-based materials. I: Influence of cement fineness, J. Mater. Civil Eng., 20, 7, 502 pp.

Davis, R.E.: 1950, A review of pozzolanic materials and their use in concretes. Symp. on Pozzolanic Materials in Mortars and Concretes, ASTM STP-99, 3-15

Fatmi, A.N.: 1977, Mesozoic. In: Shah, S.M.I. (Ed..), Stratigraphy of Pakistan. Geological Survey of Pakistan, Memoir, 12, 29-56.

Gibbons, Pat.: 1997, Pozzolans for Lime Mortars. Conservation and Repair of Ecclesiastical Buildings. http://www.buildingconservation.com/articles/pozzo/ pozz o.htm

Hemalatha, T. and Ramaswamy, A.: 2017, A review on fly ash characteristics-towards promoting high volume utilization in developing sustainable concrete. J. Clean. Prod., 147, 546-559. DOI: $10.1016 /$ j.jclepro.2017.01.114

Humphreys, K. and Mahasenan, M.: 2002, Toward a sustainable cement industry. Substudy 8: Climate change.World Business Council for Sustainable Development (WBCSD), Geneva, Switzerland.

Ingram K. and Daugherty K.: 1991, A review of limestone additions to Portland cement and concrete. Cem. Concr. Compos., 13, 3, 165-170. DOI: 10.1016/0958-9465(91)90016-B

Jones, A.G., Manistere, B.E., Oliver, R.L., Wilson, G.S. and Scott, H.S.: 1961, Reconnaissance geology of part of West Pakistan. Colombo Plan Cooperative Project, Government of Canada, Toronto, $550 \mathrm{pp}$.

Khan, S.: 2012, Biostratigraphy and microfacies of the Cretaceous sediments in the Indus Basin, Pakistan. Unpublished Ph.D Thesis, University of Edinburgh, UK.

Khurram, N., Khan, K., Saleem, M.U., Amin, M.N. and Akmal, U.: 2018, Effect of elevated temperatures on mortar with naturally occurring volcanic ash and its blend with electric arc furnace slag. Adv. Mater. Sci. Eng., 11, 5324036. DOI: 10.1155/2018/5324036
Lea, F.M.: 1976, The chemistry of cement and concrete. 3rd Edition, Edward Arnold Publishers Ltd., U.K.

Massazza, F.: 2007, Pozzolana and pozzolanic cements. In: Hewlett, P.C. (Ed.), Lea's chemistry of cement and concrete, 4th Edn., Elsevier, UK, 471-602.

Mather, K.: 1982, Current research in sulfate resistance at the waterways experiment station. Am. Concr. Inst. ACI Spec. Publ., 77, 10, 63-74. DOI: 10.14359/6420

Ombres, L. and Verre, S.: 2017, Shear performance of FRCM strengthened RC beams. Am. Concr. Inst. ACI Spec. Publ., SP 324, Farmington Hills, MI, USA.

Pan, S., Tseng, D., Lee, C.C. and Lee, C.: 2003, Influence of the fineness of sewage sludge ash on the mortar properties. Cem. Concr. Res., 33, 1749-1754. DOI: $10.1016 / \mathrm{S} 0008-8846(03) 00165-0$

Paraskeva, C., Papadakis, V., Kanellopoulou, D., Koutsoukos, P. and Angelopoulos. K.: 2007, Membrane filtration of olive mill wastewater and exploitation of its fractions. Water Environ. Res., 79, 4, 421-429. DOI:10.2175/106143006X115345

Roadmap: 2009, Carbon emissions reductions up to 2050, WBCSD-EA, Geneva, Switzerland.

Sabir, B., Wild, S., and Bai, J.: 2001, Metacaolin and calcined clays as pozzolans for concrete: a review. Cem. Concr. Compos, 23, 6, 441-454. DOI: 10.1016/S0958-9465(00)00092-5

Setina, J., Gabrene, A. and Juhnevica, I.: 2013, Effect of pozzolanic additives on structure and chemical durability of concrete. Procedia Eng., 57, 1005-1012. DOI: 10.1016/j.proeng.2013.04.127

Shah, S.M.I.: 2009, Stratigraphy of Pakistan. Geological Survey of Pakistan Memoirs, 22.

Spence, R.J.S. and Cook, D.J.: 1983, Building materials in developing countries. Wiley, London, 125-157.

Suhendro, B.: 2014, Toward green concrete for better sustainable environment. Procedia Eng., 95, 305-320. DOI: 10.1016/j.proeng.2014.12.190

Taylor, P.C.: 2008, Specifications and protocols for acceptance tests on processing additions in cement manufacturing. National Cooperative Highway Research Program, NCHRP Report, 607, 1-96.

Troxell, G.E., Davis, H.E. and Kelly, J.W.: 1968, Composition and properties of concrete. McGrawHill., New York, 529 pp.

Turanli, L., Uzal, B. and Bektas F.: 2005, Influence of natural pozzolana content on self-compacting concrete durability properties. Cem. Concr. Res., 35, 6, 11061111. DOI: 10.1016/j.cemconres.2004.07.022

WBCSD-IEA. Cement Technology Roadmap: 2009, Carbon Emissions Reductions up to 2050. WBCSD-IEA, Geneva, Switzerland.

Yang, K.H., Jung, Y.B., Cho, M.S. and Tae, S.H.: 2016, Effect of supplementary cementitious materials on reduction of $\mathrm{CO}_{2}$ emissions from Concrete. In: Handbook of Low Carbon Concrete, 1st ed., Butterworth-Heinemann, Oxford, UK, 89-110. DOI: 10.1016/B978-0-12-804524-4.00005-1 